\title{
Analisis Kemampuan Pemecahan Masalah Matematis Siswa SMP Berdasarkan Gender
}

\author{
Refli Annisa ${ }^{1}$, Yenita Roza ${ }^{* 2}$, Maimunah ${ }^{3}$ \\ Program Studi Pascasarjana Pendidikan Matematika, \\ Fakultas Keguruan dan Ilmu Pendidikan, Universitas Riau \\ *Corresponding Author. Email: yenita.roza@lecturer.unri.ac.id
}

\begin{abstract}
The purpose of this study was to analyze the mathematical problem Article History solving abilities of junior high school students based on the gender of the students. Received: 05-03-2021 This research is a qualitative descriptive study. The subjects in this study were 24 Revised: 10-05-2021 students of class VIII SMPN 3 Bangkinang consisting of 12 male students and 12 Accepted: 16-05-2021 female students. Then 6 subjects were selected, namely 3 men and 3 women who Published: 07-06-2021 had high, medium, and low category mathematical problem solving abilities. The results of the answers would be described in answering the questions. The research was conducted in the even semester of the 2020/2021 school year. The analysis Key Words: was carried out by giving a written test in the form of description questions, Mathematical amounting to 3 questions. The material being tested is the material cubes and Problem Solving blocks. The results showed that the mathematical problem solving abilities of Skills, female students were superior to male students.

Gender.

Abstrak: Tujuan penelitian ini adalah untuk menganalisis kemampuan pemecahan Sejarah Artikel masalah matematis siswa SMP berdasarkan gender siswa. Penelitian ini adalah Diterima: 05-03-2021 penelitian deskriptif kualitatif. Subjek pada penelitian ini adalah siswa kelas VIII Direvisi: 10-05-2021 SMPN 3 Bangkinang yang berjumlah 24 orang siswa terdiri dari 12 siswa laki-laki Disetujui: 16-05-2021 dan 12 siswa perempuan. Kemudian dipilih 6 subjek, yaitu 3 laki-laki dan 3 Diterbitkan: 07-06-2021 perempuan yang memiliki kemampuan pemecahan masalah matematis kategori tinggi, sedang, dan rendah yang akan diuraikan hasil jawabannya dalam menjawab soal. Penelitian dilakukan pada semester genap tahun ajaran 2020/2021. Analisis Kata Kunci: dilakukan dengan memberikan tes tertulis berbentuk soal uraian yang berjumlah 3 Kemampuan Pemecahan soal. Materi yang diujikan adalah materi kubus dan balok. Hasil penelitian Masalah Matematis, menunjukkan bahwa kemampuan pemecahan masalah matematis siswa perempuan Gender. lebih unggul daripada siswa laki-laki.
\end{abstract}

How to Cite: Annisa, R., Roza, Y., \& Maimunah, M. (2021). Analisis Kemampuan Pemecahan Masalah Matematis Siswa SMP Berdasarkan Gender. Jurnal Kependidikan: Jurnal Hasil Penelitian dan Kajian Kepustakaan di Bidang Pendidikan, Pengajaran dan Pembelajaran, 7(2), 481-490. doi:https://doi.org/10.33394/jk.v7i2.3688

https://doi.org/10.33394/jk.v7i2.3688

This is an open-access article under the CC-BY-SA License.

\section{Pendahuluan}

Kemampuan pemecahan masalah adalah salah satu kemampuan yang harus dikuasai siswa pada pembelajaran matematika. Sebagaimana yang diungkapkan oleh (Ulya \& Kartono, 2014) yang menyatakan bahwa matematika tidak bisa dipisahkan dengan pemecahan masalah. Sejalan dengan hal itu, (Hidayat \& Sariningsih, 2018) mengungkapkan bahwa dalam pembelajaran matematika pemecahan masalah merupakan inti dari kemampuan yang mendasar pada kegiatan pembelajaran. Kemampuan pemecahan masalah matematis memberikan kontribusi yang besar dalam menyelesaikan permasalah pada kehidupan nyata atau kehidupan sehari-hari.

Pemecahan masalah menuntut siswa hanya bukan sekedar memahami, tetapi juga mampu menggunakan sejumlah strategi dalam menyelesaikan sebuah permasalahan. Dahar 
(Sundayana, 2016) mengungkapkan bahwa pemecahan masalah adalah kegiatan manusia yang menggabungkan konsep serta aturan yang telah diperoleh sebelumnya, dan bukan suatu keterampilan generik. Sejalan dengan hal itu, (Andayani \& Lathifah, 2019) mengatakan kemampuan pemecahan masalah merupakan potensi yang dimiliki seseorang atau siswa dalam menyelesaikan soal cerita, menyelesaikan soal yang tidak rutin (berbeda-beda), serta mengaplikasikan matematika dalam kehidupan sehari-hari untuk menemukan solusi atau memecahkan persoalan yang terdapat pada matematika.

Pada pembelajaran matematika, kemampuan pemecahan masalah menjadi kemampuan yang penting untuk dimiliki siswa karena dalam setiap proses pembelajaran maupun penyelesaiannya, siswa dimungkinkan memperoleh pengalaman menggunakan pengetahuan serta keterampilan yang sudah dimiliki sebelumnya untuk kemudian diterapkan sebagai pemecahan masalah pada situasi yang baru (Lahinda \& Jailani, 2015). Sejalan dengan hal itu (Suratmi \& Purnami, 2017) mengemukakan bahwa dalam menyelesaikan masalah siswa harus mempunyai kemampuan pemecahan masalah yang baik yang akan membantunya dalam proses pembelajaran. Hal ini menunjukan bahwa jika siswa memiliki kemampuan pemecahan masalah, maka akan memudahkan siswa tersebut untuk mengatasi masalah khususnya masalah yang berkaitan dengan kehidupan sehari-hari dengan menggunakan pengetahuan ataupun pemahaman, serta keterampilan yang telah dimilikinya.

Akan tetapi, fakta di lapangan menunjukkan bahwa masih banyak siswa SMP yang kesulitan dalam menjawab soal tes kemampuan pemecahan masalah matematis sehingga kemampuan pemecahan masalah matematis siswa SMP masih terbilang rendah. Hal ini ditunjukkan dari hasil penelitian yang dilakukan (Chotimah et al., 2019) yang mengungkapkan bahwa kemampuan pemecahan masalah matematik siswa SMP kelas VIII di salah satu SMP di Kabupaten Bandung Barat pada materi bangun ruang sisi datar termasuk dalam kategori rendah. Hal ini dapat dilihat dari persentase kemampuan pemecahan masalah matematik siswa hanya mencapai $43 \%$. Rendahnya kemampuan matematis pada siswa MTS juga ditunjukkan oleh (Mariam et al., 2019) yang dimana hasil penelitiannya menjelaskan bahwa dalam memahami masalah, menentukan model yang akan dipakai, menuntaskan masalah, dan melihat kembali hasil pekerjaannya tergolong rendah dengan persentase $56,5 \%$ dari skor siswa yang berjumlah 226 dengan jumlah siswa adalah 20.

Siswa laki-laki dan perempuan memiliki kemampuan yang berbeda-beda dalam menyelesaikan soal pemecahan masalah matematis. (Mubeen et al., 2013) menjelaskan bahwa anak laki-laki dan anak perempuan memiliki perbedaan dalam pencapaian prestasi matematika. Hal ini sejalan dengan yang diungkapkan $(\mathrm{Mz}, 2013)$ bahwa siswa yang memiliki gender berbeda tentu memiliki banyak perbedaan dalam mempelajari matematika. Berdasarkan perbedaan tersebut guru harus menyadari dan memperhatikan bahwa masingmasing gender memiliki karakteristik masing-masing (Ayuni, 2018). Maka dari itu, perbedaan gender dapat menjadi salah satu faktor yang menjadi pembeda seseorang dalam menentukan pemecahan masalah matematis. Menurut (Nur \& Palobo, 2018) ketika dihadapkan pada soal yang berbasis pemecahan masalah, siswa laki-laki dan perempuan memiliki kecenderungan pemecahan masalah yang berbeda. Ketika dihadapkan pada soal yang berbasis pemecahan masalah, siswa laki-laki dan perempuan memiliki kecenderungan pemecahan masalah yang berbeda.

(Nurhayati, 2018) mengemukakan bahwa umumnya perempuan kerap dicitrakan dan mencitrakan dirinya sebagai makhluk yang emosional, mudah menyerah, pasif, subjektif, lemah dalam matematika, mudah terpengaruh, lemah fisik, dan dorongan seksnya rendah. 
Sedangkan laki-laki sering dicitrakan dan mencitrakan dirinya sebagai makhluk yang rasional, logis, mandiri, agresif, kompetitif, objektif, senang berpetualang, aktif, memiliki fisik dan dorongan seks yang kuat. Sementara itu, dalam kemampuan pemecahan masalah matematis. Kemudian dalam menjawab soal matematika, (Mz, 2013) mengungkapkan siswa laki-laki cenderung menggunakan strategi spatial sedangkan siswa perempuan lebih menggunakan strategi verbal melalui petunjuk yang diberikan pada soal. Lebih lanjut (Susilowati, 2016) mengungkapkan siswa perempuan lebih unggul dalam ketepatan, kecermatan, ketelitian, dan keseksamaan berpikir/bernalar dalam pemecahan masalah dan siswa laki-laki lebih unggul pada proses menyimpulkan dari suatu pernyataan dan penerapan logika dalam pemecahan masalah. Berdasarkan uraian tersebut menunjukkan adanya keberagaman mengenai peran gender dalam pembelajaran matematika. Oleh karena itu, penelitian ini bertujuan untuk menganalisis perbedaan kemampuan pemecahan masalah matematis siswa SMP berdasarkan gender.

\section{Metode Penelitian}

Penelitian ini merupakan penelitian deskriptif kualitatif untuk meneliti perbedaan kemampuan pemecahan masalah matematis yang dimiliki oleh siswa laki-laki dan siswa perempuan. Subjek dalam penelitian ini adalah siswa kelas VIII SMP Negeri 3 Bangkinang tahun ajaran 2020/2021 yang berjumlah 24 siswa, terdiri dari 12 siswa laki-laki dan 12 siswa perempuan. Kemudian dipilih 6 subjek, yaitu 3 laki-laki dan 3 perempuan yang memiliki kemampuan pemecahan masalah matematis kategori tinggi, sedang, dan rendah yang akan diuraikan hasil jawabannya dalam menjawab soal. Hasil ulangan harian dijadikan acuan untuk pemilihan subjek penelitian dengan interval penilaian yaitu:

\section{Tabel 1. Konversi Nilai Menjadi Kategori Kemampuan}

\begin{tabular}{cc}
\hline Nilai $(\%)$ & Kategori kemampuan siswa \\
\hline $80,0 \leq$ nilai $\leq 100$ & Tinggi \\
\hline $60,0 \leq$ nilai $<80,0$ & Sedang \\
\hline nilai $<60,0$ & Rendah \\
\hline
\end{tabular}

Sumber: (Buranda \& Bernard, 2018)

Tes kemampuan pemecahan masalah matematis yang diberikan berupa tes tertulis berbentuk soal uraian yang berjumlah 3 soal dengan tingkat kesulitan sedang. Materi yang diujikan adalah materi kubus dan balok. Soal yang diujikan adalah soal yang digunakan(Raya, 2019) dalam penelitiannya yang sebelumnya sudah dilakukan perhitungan validitas, reliabilitas, daya pembeda, dan tingkat kesukaran soal. Kemampuan pemecahan masalah matematis siswa diukur berdasarkan indikator yang diungkapkan oleh Polya menurut Nirmalitasari dalam (Rostika \& Junita, 2017), antara lain: (1) Memahami masalah, meliputi mengidentifikasi unsur yang diketahui, yang ditanyakan dan kecukupan unsur yang diperlukan, (2) Menyusun rencana pemecahan masalah, meliputi merumuskan masalah matematika atau menyusun model matematikanya, (3) Melaksanakan rencana pemecahan masalah, meliputi menerapkan strategi penyelesaian berbagai masalah di dalam atau di luar matematika, (4) Memeriksa kembali hasil, meliputi menjelaskan atau menginterpretasikan hasil sesuai dengan permasalahan asal.

\section{Hasil Penelitian dan Pembahasan}

Subjek penelitian ini adalah 6 orang siswa yang terdiri atas 3 orang siswa laki-laki dan 3 orang siswa perempuan. Keenam orang siswa tersebut dikategorikan siswa yang memiliki 
kemampuan kognitif tinggi, sedang, dan rendah berdasarkan perolehan nilai ulangan harian siswa yang berada pada interval nilai tinggi, sedang, dan rendah.

Tabel 2. Hasil Ulangan Harian Siswa

\begin{tabular}{|c|c|c|c|c|}
\hline No & Nama Siswa & Jenis Kelamin & Hasil Ulangan Harian & Kategori Penilaian \\
\hline 1 & S1 & $\mathrm{L}$ & 88 & Tinggi \\
\hline 2 & S2 & $\mathrm{L}$ & 85 & Tinggi \\
\hline 3 & S3 & $\mathrm{L}$ & 79 & Sedang \\
\hline 4 & S4 & $\mathrm{L}$ & 79 & Sedang \\
\hline 5 & S5 & $\mathrm{L}$ & 79 & Sedang \\
\hline 6 & S6 & $\mathrm{L}$ & 77 & Sedang \\
\hline 7 & S7 & $\mathrm{L}$ & 75 & Sedang \\
\hline 8 & S8 & $\mathrm{L}$ & 58 & Rendah \\
\hline 9 & S9 & $\mathrm{L}$ & 58 & Rendah \\
\hline 10 & S10 & $\mathrm{L}$ & 56 & Rendah \\
\hline 11 & S11 & $\mathrm{L}$ & 56 & Rendah \\
\hline 12 & S12 & $\mathrm{L}$ & 55 & Rendah \\
\hline 13 & S13 & $\mathrm{P}$ & 89 & Tinggi \\
\hline 14 & S14 & $\mathrm{P}$ & 88 & Tinggi \\
\hline 15 & S15 & $\mathrm{P}$ & 82 & Tinggi \\
\hline 16 & S16 & $\mathrm{P}$ & 79 & Sedang \\
\hline 17 & S17 & $\mathrm{P}$ & 78 & Sedang \\
\hline 18 & S18 & $\mathrm{P}$ & 78 & Sedang \\
\hline 19 & S19 & $\mathrm{P}$ & 76 & Sedang \\
\hline 20 & S20 & $\mathrm{P}$ & 75 & Sedang \\
\hline 21 & S21 & $\mathrm{P}$ & 58 & Rendah \\
\hline 22 & $\mathrm{~S} 22$ & $\mathrm{P}$ & 55 & Rendah \\
\hline 23 & S23 & $\mathrm{P}$ & 55 & Rendah \\
\hline 24 & S24 & $\mathrm{P}$ & 53 & Rendah \\
\hline
\end{tabular}

Selanjutnya setelah dipilih 6 subjek yaitu 3 laki-laki dan 3 perempuan yang memiliki kemampuan pemecahan masalah matematis kategori tinggi, sedang, dan rendah berdasarkan Tabel 2, maka hasil analisis tes tertulis setiap subjek dijabarkan sebagai berikut:

1) Analisis Kemampuan Pemecahan Masalah Matematis Subjek Berjenis Kelamin Laki-laki dan Perempuan Kategori Tinggi
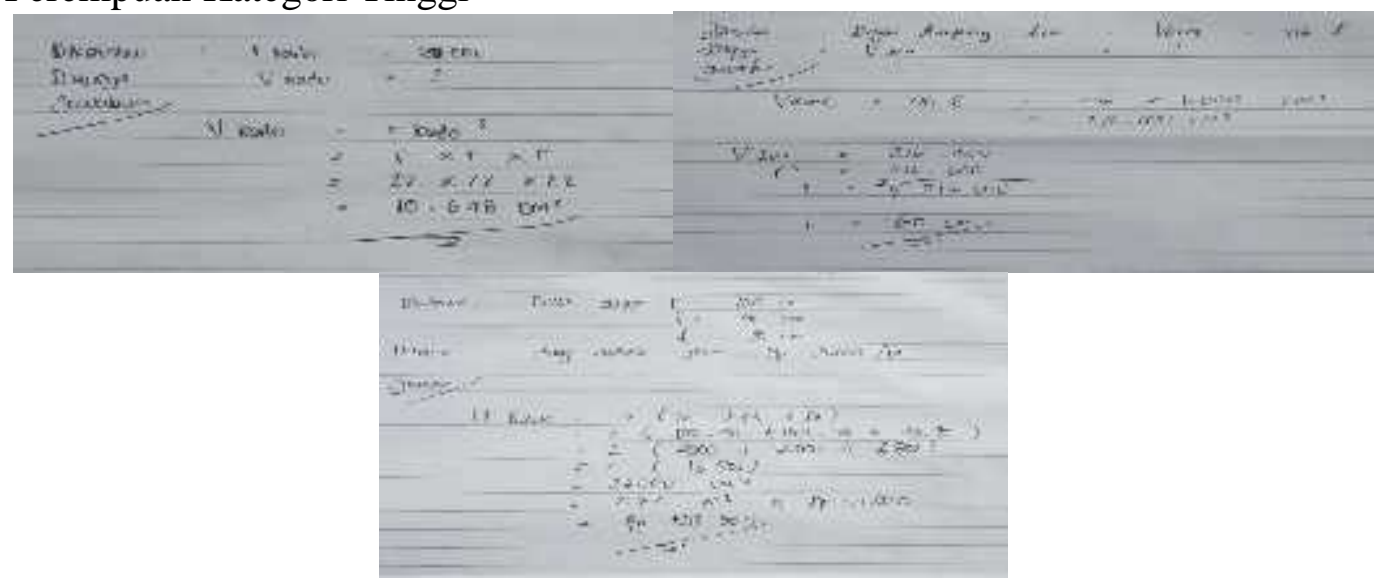

\section{Gambar 1. Jawaban Subjek Laki-Laki Kategori Tinggi}


Pada jawaban subjek berjenis kelamin laki-laki dengan kategori tinggi, subjek sudah mampu memahami masalah dari soal yang diberikan. Hal ini terlihat dari hasil jawaban siswa dimana subjek tepat dalam menuliskan apa yang diketahui dan apa yang ditanyakan dari 3 soal yang tersebut. Selanjutnya semua jawaban dijawab dengan benar, hanya saja subjek cenderung mengabaikan memeriksa kembali hasil jawaban. Kegiatan memeriksa kembali berupa pemeriksaan secara khusus pada setiap langkah penyelesaian dan pemeriksaan secara umum untuk mengetahui masalah secara umum (Nadhifa et al., 2019). Hal ini berupa membuat kesimpulan dari jawaban.

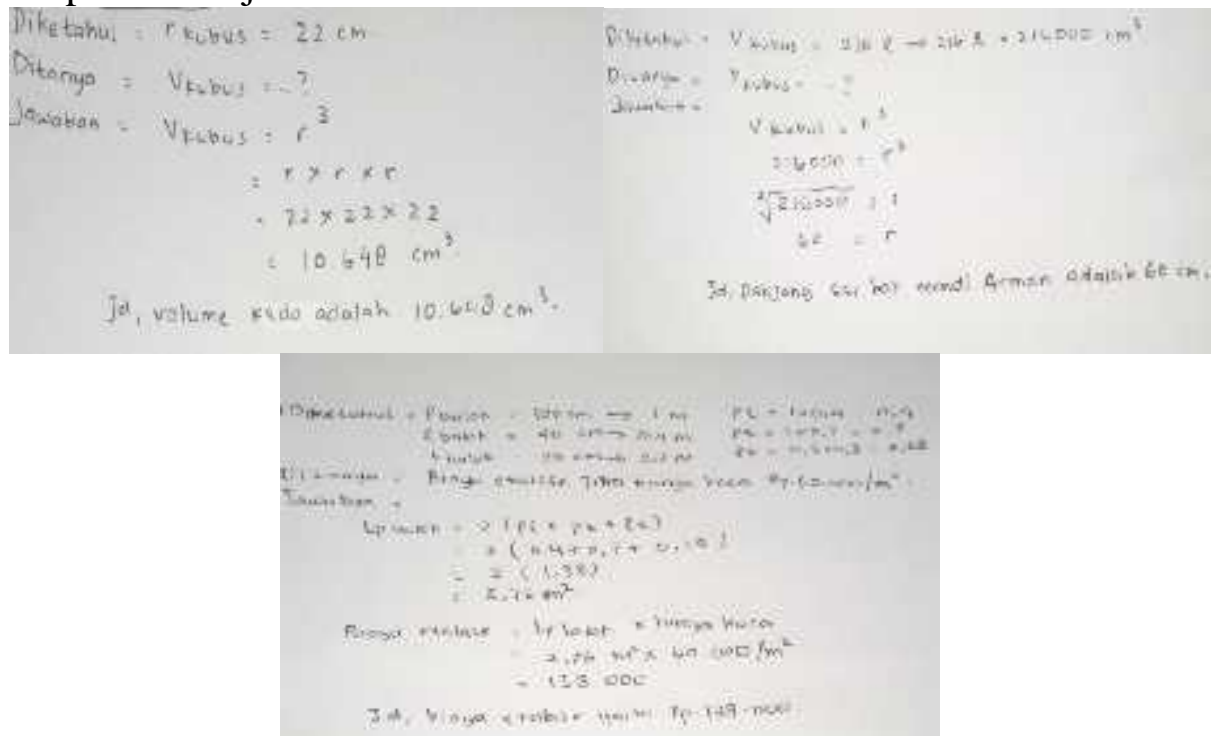

\section{Gambar 2. Jawaban Subjek Perempuan Kategori Tinggi}

Pada jawaban subjek berjenis kelamin perempuan dengan kategori tinggi, tidak jauh berbeda dengan subjek laki-laki, pada indikator pertama yaitu memahami masalah, subjek perempuan sudah tepat dalam menuliskan apa yang diketahui dan apa yang ditanyakan pada soal. Subjek perempuan menyelesaikan masalah yang diberikan sesuai dengan strategi yang telah direncanakan urut mulai dari hal yang diketahui hingga hasil akhir ditemukan. Semua jawaban dijawab dengan tepat dengan jawaban yang mudah dipahami.

2) Analisis Kemampuan Pemecahan Masalah Matematis Subjek Berjenis Kelamin Laki-laki dan Perempuan Kategori Sedang

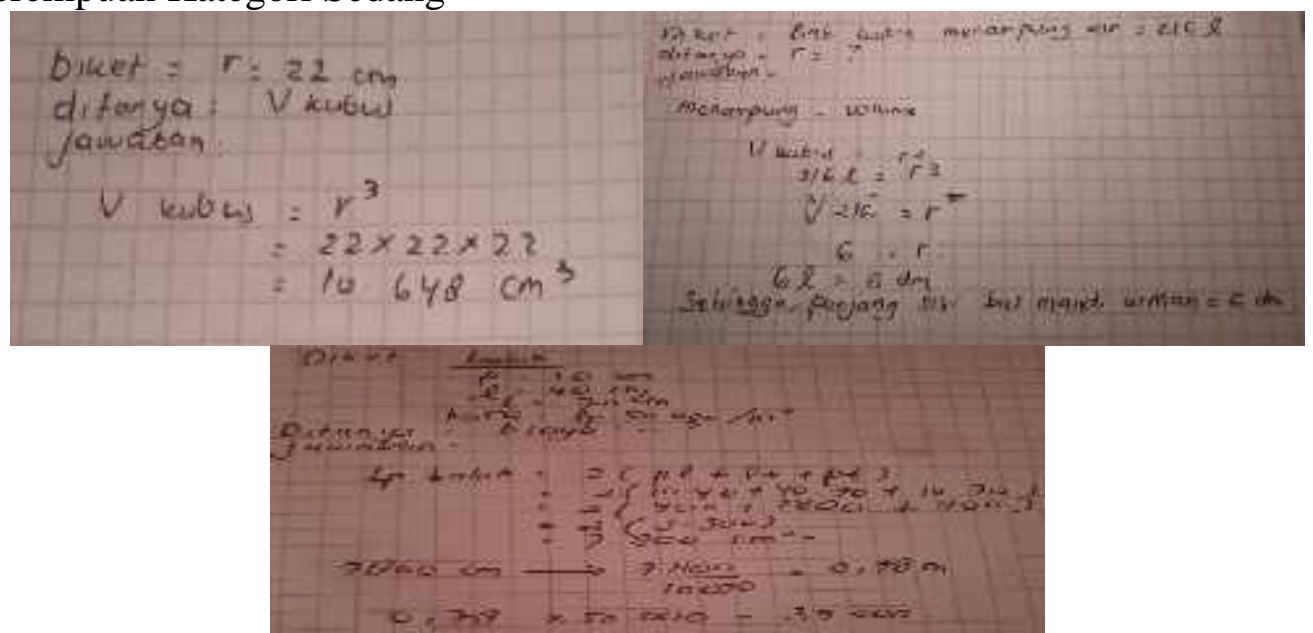

\section{Gambar 3. Jawaban Subjek Laki-Laki Kategori Sedang}


Pada jawaban subjek berjenis kelamin laki-laki dengan kategori sedang, subjek sudah mampu memahami masalah dimana subjek mampu menuliskan apa yang diketahui dan apa yang ditanyakan pada soal. Akan tetapi, dalam melakukan perhitungan subjek masih keliru dan kurang teliti sehingga beberapa proses penyelesaian menjadi salah. Subjek cenderung mengabaikan memeriksa kembali hasil jawaban pada soal nomor 1 dan 3.

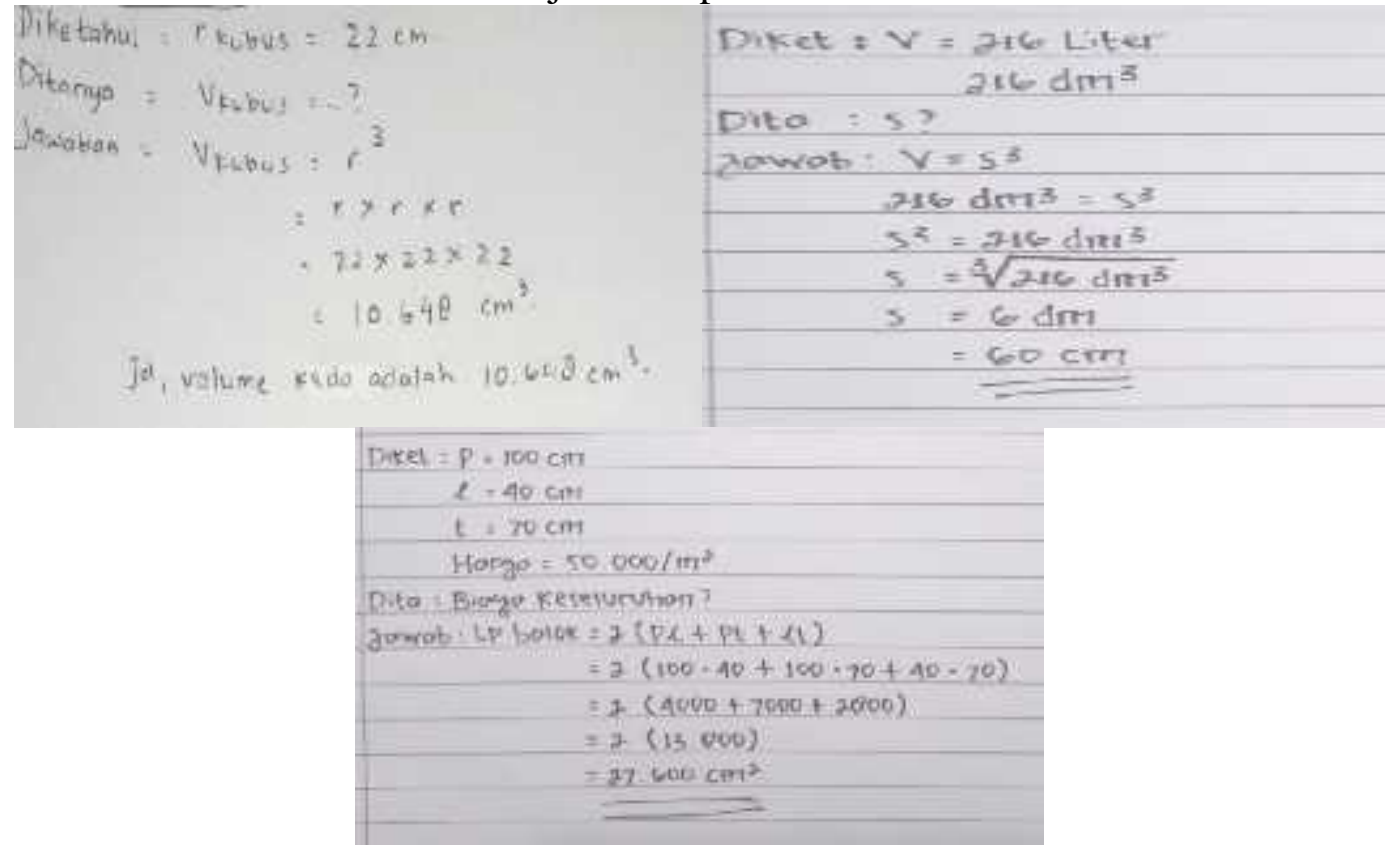

\section{Gambar 4. Jawaban Subjek Perempuan Kategori Sedang}

Pada jawaban subjek berjenis kelamin perempuan dengan kategori sedang, subjek sudah mampu memahami masalah dimana subjek menuliskan apa yang diketahui dan apa yang ditanyakan pada soal. Subjek juga sudah mampu menyusun rencana dan melaksanakan rencana, walaupun dalam menjawab soal nomor 3 jawaban siswa tidak lengkap sehingga jawaban akhir tidak sesuai dengan yang diminta soal. Subjek juga cenderung mengabaikan memeriksa kembali hasil jawaban yaitu pada soal nomor 2 dan 3.

3) Analisis Kemampuan Pemecahan Masalah Matematis Subjek Berjenis Kelamin Laki-laki dan Perempuan Kategori Rendah

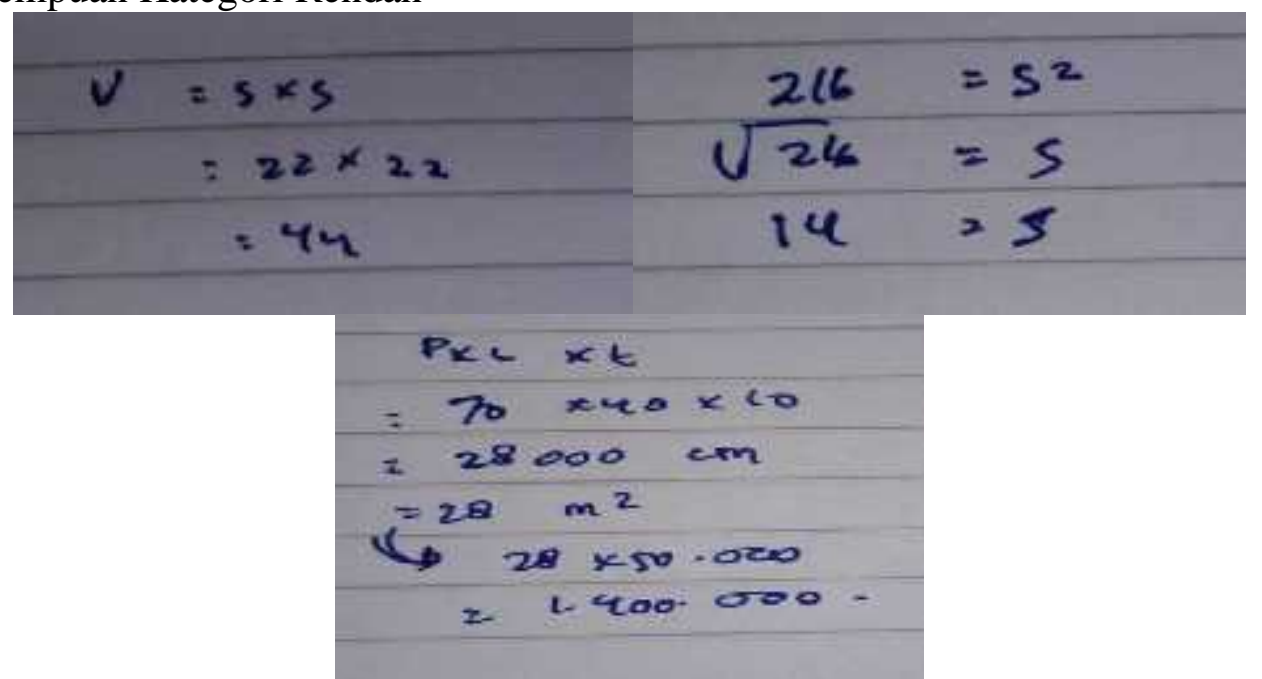

Gambar 5. Jawaban Subjek Laki-Laki Kategori Rendah 
Pada jawaban subjek berjenis kelamin laki-laki dengan kategori rendah, subjek belum mampu memahami masalah dimana subjek tidak menuliskan apa yang diketahui dan apa yang ditanyakan pada soal. Subjek juga tidak melakukan langkah-langkah penyelesaian dengan tepat, melakukan perhitungan secara asal dan menebak-nebak.

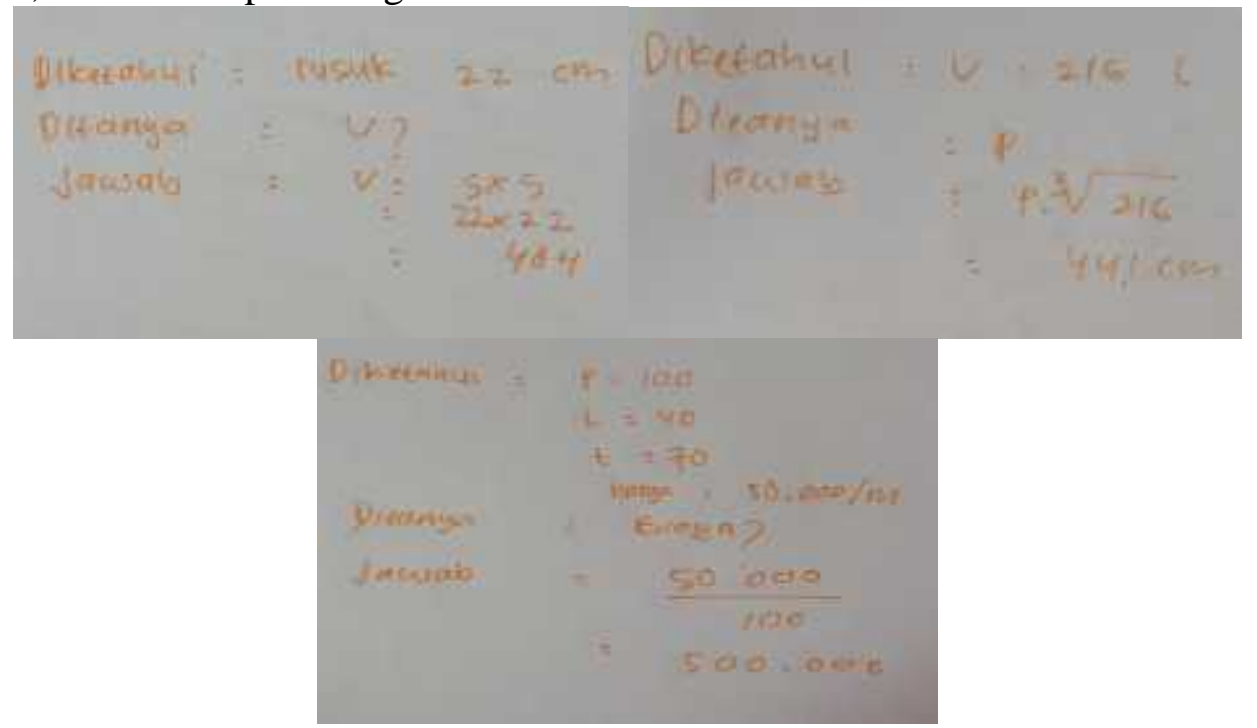

Gambar 6. Jawaban Subjek Perempuan Kategori Rendah

Tidak jauh berbeda dengan subjek laki-laki, jawaban subjek berjenis kelamin perempuan dengan kategori rendah juga tidak dapat melakukan perencanaan penyelesaian masalah dengan benar serta melakukan perhitungan secara asal dan sulit dipahami. Akan tetapi siswa sudah mampu memahami masalah dimana siswa menuliskan apa yang diketahui dan apa yang ditanyakan pada soal.

Selanjutnya berdasarkan hasil tes tertulis terhadap 24 siswa, juga diperoleh persentase jumlah siswa yang menjawab benar pada setiap indikator perbutir soal yang akan disajikan berdasarkan gender laki-laki dan perempuan. Persentase jumlah siswa yang menjawab benar pada setiap indikator perbutir soal pada siswa laki-laki disajikan pada Tabel 2 berikut.

Tabel 3. Persentase Jumlah Siswa yang Menjawab Benar pada Setiap Indikator Perbutir Soal pada Siswa Laki-Laki

\begin{tabular}{lcccc}
\hline \multirow{2}{*}{ Indikator } & \multicolumn{2}{c}{$\begin{array}{c}\text { Persentase Jumlah Siswa yang Menjawab } \\
\text { Benar Setiap Indikator Perbutir Soal }\end{array}$} & \multirow{2}{*}{$\begin{array}{c}\text { Persentase } \\
\text { Rata-Rata }\end{array}$} \\
\cline { 2 - 4 } & Soal 1 & Soal 2 & Soal 3 & \\
\hline Memahami masalah & $91,67 \%$ & $75 \%$ & $83,33 \%$ & $83,33 \%$ \\
\hline $\begin{array}{l}\text { Membuat rencana } \\
\text { pemecahan masalah }\end{array}$ & $75 \%$ & $58,33 \%$ & $66,67 \%$ & $66,67 \%$ \\
\hline $\begin{array}{l}\text { Melaksanakan } \\
\text { rencana pemecahan } \\
\text { masalah }\end{array}$ & $41,67 \%$ & $33,33 \%$ & $16,67 \%$ & $30,45 \%$ \\
\hline $\begin{array}{l}\text { Memeriksa kembali } \\
\text { hasil }\end{array}$ & $25 \%$ & $16,67 \%$ & $16,67 \%$ & $19,45 \%$ \\
\hline
\end{tabular}

Tabel 3 diatas memperlihatkan bahwa indikator yang memiliki persentase rata-rata paling tinggi pada siswa laki-laki, yaitu pada indikator memahami masalah dengan persentase rata-ratanya adalah $83,33 \%$. Selanjutnya indikator dengan persentase paling rendah terdapat pada indikator memeriksa kembali hasil dengan persentase rata-ratanya adalah $19,45 \%$. 
Berikut persentase jumlah siswa yang menjawab benar pada setiap indikator perbutir soal pada siswa perempuan yang disajikan dalam Tabel 4 berikut ini.

Tabel 4. Persentase Jumlah Siswa yang Menjawab Benar pada Setiap Indikator Perbutir Soal pada Siswa Perempuan

\begin{tabular}{lcccc}
\hline \multirow{1}{*}{ Indikator } & \multicolumn{2}{c}{$\begin{array}{c}\text { Persentase Jumlah Siswa yang Menjawab } \\
\text { Benar Setiap Indikator Perbutir Soal }\end{array}$} & \multirow{2}{*}{$\begin{array}{c}\text { Persentase } \\
\text { Rata-Rata }\end{array}$} \\
\cline { 2 - 4 } & Soal 1 & Soal 2 & Soal 3 & \\
\hline Memahami masalah & $91,67 \%$ & $83,33 \%$ & $83,33 \%$ & $86,11 \%$ \\
\hline $\begin{array}{l}\text { Membuat rencana } \\
\text { pemecahan masalah }\end{array}$ & $66,67 \%$ & $75 \%$ & $66,67 \%$ & $69,45 \%$ \\
\hline $\begin{array}{l}\text { Melaksanakan } \\
\text { rencana pemecahan } \\
\text { masalah }\end{array}$ & $66,67 \%$ & $58,33 \%$ & $58,33 \%$ & $61,11 \%$ \\
\hline $\begin{array}{l}\text { Memeriksa kembali } \\
\text { hasil }\end{array}$ & $16,67 \%$ & $25 \%$ & $16,67 \%$ & $19,45 \%$ \\
\hline
\end{tabular}

Sama halnya dengan siswa laki-laki, berdasarkan Tabel 4 terlihat bahwa indikator yang memiliki persentase rata-rata paling tinggi pada siswa perempuan, yaitu juga terletak pada indikator memahami masalah dengan persentase rata-ratanya adalah $86,11 \%$. Selanjutnya indikator dengan persentase paling rendah terdapat pada indikator memeriksa kembali hasil dengan persentase rata-ratanya adalah 19,45\%.

Berdasarkan persentase rata-rata jumlah siswa yang menjawab benar pada setiap indikator perbutir soal pada siswa laki-laki dan siswa perempuan yang telah disajikan dalam Tabel 3 dan Tabel 4, maka didapatkan perbandingan persentase rata-rata yang disajikan pada Tabel 5 berikut.

Tabel 5. Perbandingan Persentase Rata-Rata Jumlah Siswa yang Menjawab Benar Setiap Indikator

\begin{tabular}{lcc}
\hline \multirow{1}{*}{ Indikator } & $\begin{array}{c}\text { Persentase Rata-Rata Jumlah Siswa yang Menjawab } \\
\text { Benar Pada Setiap Indikator }\end{array}$ \\
\cline { 2 - 3 } & Laki-Laki & Perempuan \\
\hline Memahami masalah & $83,33 \%$ & $86,11 \%$ \\
\hline $\begin{array}{l}\text { Membuat rencana } \\
\text { pemecahan masalah }\end{array}$ & $66,67 \%$ & $69,45 \%$ \\
\hline $\begin{array}{l}\text { Melaksanakan rencana } \\
\text { pemecahan masalah }\end{array}$ & $30,45 \%$ & $61,11 \%$ \\
\hline Memeriksa kembali hasil & $19,45 \%$ & $19,45 \%$
\end{tabular}

Pada Tabel 5 diatas, terlihat bahwa kemampuan pemecahan masalah matematis siswa berjenis kelamin laki-laki dan perempuan terdapat perbedaan dalam ketercapaian indikator kemampuan pemecahan masalah matematis. Dapat dilihat bahwa persentase rata-rata siswa berjenis kelamin perempuan lebih tinggi daripada persentase rata-rata siswa laki-laki pada indikator pertama yaitu memahami masalah, pada indikator kedua, yaitu indikator membuat rencana penyelesaian, dan pada indikator ketiga, yaitu melaksanakan rencana penyelesaian.

Berdasarkan data yang telah diuraikan diatas, dapat disimpulkan bahwa kemampuan pemecahan masalah matematis siswa perempuan lebih unggul dibanding siswa laki-laki. Hal ini sejalan dengan hasil penelitian yang telah dilakukan oleh (Davita \& Pujiastuti, 2020) yang mengungkapkan bahwa perempuan lebih baik dalam memecahkan masalah matematika daripada siswa laki-laki. Kemudian (Buranda \& Bernard, 2018) juga telah melakukakan 
penelitian yang hasilnya menyebutkan bahwa Dalam hitungan rata-rata, aspek kognitif kemampuan pemecahan masalah pada siswa perempuan adalah lebih baik daripada siswa laki-laki. Lebih lanjut (Anggraeni \& Herdiman, 2018) telah melakukakan penelitian serupa, dimana dari penelitian tersebut diperoleh bahwa subjek perempuan lebih unggul daripada laki-laki pada semua indikator pemecahan masalah walaupun keunggulan tersebut tidak begitu signifikan.

\section{Kesimpulan}

Hasil penelitian ini menunjukkan bahwa kemampuan pemecahan masalah siswa perempuan lebih unggul daripada siswa laki-laki. Hal ini dilihat dari perbandingan persentase rata-rata jumlah subjek yang menjawab benar pada setiap indikator yang diperoleh masing-masing subjek laki-laki dan perempuan, dimana subjek perempuan mendapatkan persentase rata-rata lebih tinggi dibandingkan subjek laki-laki pada indikator pertama yaitu memahami masalah, pada indikator kedua, yaitu indikator membuat rencana penyelesaian, dan pada indikator ketiga, yaitu melaksanakan rencana penyelesaian.

\section{Saran}

Berdasarkan penelitian yang telah dilakukan, diharapkan guru bisa memperhatikan bahwa masing-masing gender memiliki karakteristik masing-masing serta diharapkan guru dapat memberikan soal-soal dengan kompleksitas masalah yang bervariasi sehingga siswa bisa terlatih untuk menyelesaikan masalah yang diberikan. Selanjutnya diharapkan untuk peneliti lainnya untuk kedepan bisa melakukan penelitian lebih dalam mengenai kemampuan pemecahan masalah matematis berdasarkan gender.

\section{Daftar Pustaka}

Andayani, F., \& Lathifah, A. N. (2019). Analisis Kemampuan Pemecahan Masalah Siswa SMP dalam Menyelesaikan Soal Pada Materi Aritmatika Sosial. Jurnal Cendekia: Jurnal Pendidikan Matematika, 3(1), 1-10.

Anggraeni, R., \& Herdiman, I. (2018). Kemampuan Pemecahan Masalah Matematik Siswa SMP pada Materi Lingkaran Berbentuk Soal Kontekstual Ditinjau dari Gender. Numeracy, 5(1), 19-28.

Ayuni, D. R. (2018). Profil Pemecahan Masalah Matematis Siswa Berdasarkan Perbedaan Gender Pada Materi Geometri di Kelas XI Keperawatan 1 SMK Muhammadiyah 7 Gondanglegi. University Of Muhammadiyah Malang.

Buranda, M. S., \& Bernard, M. (2018). Analisis Kemampuan Pemecahan Masalah Matematik Materi Lingkaran Siswa SMP Berdasarkan Gender. JPMI (Jurnal Pembelajaran Matematika Inovatif), 1(1), 33-40.

Chotimah, S., Sari, I. P., \& Zanthy, L. S. (2019). Analisis Kemampuan Pemecahan Masalah Matematik Siswa SMP Pada Materi Kubus dan Balok. Jurnal Ilmiah P2M STKIP Siliwangi, 6(2), 86-89.

Davita, P. W. C., \& Pujiastuti, H. (2020). Anallisis Kemampuan Pemecahan Masalah Matematika Ditinjau Dari Gender. Kreano, Jurnal Matematika Kreatif-Inovatif, 11(1), $110-117$.

Hidayat, W., \& Sariningsih, R. (2018). Kemampuan Pemecahan Masalah Matematis dan Adversity Quotient Siswa SMP Melalui Pembelajaran Open Ended. JNPM (Jurnal Nasional Pendidikan Matematika), 2(1), 109-118. 
Lahinda, Y., \& Jailani, J. (2015). Analisis Proses Pemecahan Masalah Matematika Siswa Sekolah Menengah Pertama. Jurnal Riset Pendidikan Matematika, 2(1), 148-161.

Mariam, S., Rohaeti, E. E., \& Sariningsih, R. (2019). Analisis Kemampuan Pemecahan Masalah Matematis Siswa Madrasah Aliyah Pada Materi Pola Bilangan. Journal on Education, 1(2), 156-162.

Mubeen, S., Saeed, S., \& Arif, M. H. (2013). Attitude Towards Mathematics and Academic Achievement in Mathematics among Secondary Level Boys and Girls. Journal of Humanities and Social Science, 6(4), 38-41.

Mz, Z. A. (2013). Perspektif Gender dalam Pembelajaran Matematika. Marwah: Jurnal Perempuan, Agama Dan Jender, 12(1), 14-31.

Nadhifa, N., Maimunah, M., \& Roza, Y. (2019). Analisis Kemampuan Pemecahan Masalah Siswa Kelas VIII SMPN 1 Rambah Samo pada Materi Bangun Ruang Sisi Datar. Numerical: Jurnal Matematika Dan Pendidikan Matematika, 3(1), 63-76.

Nur, A. S., \& Palobo, M. (2018). Profil Kemampuan Pemecahan Masalah Matematika Siswa Ditinjau dari Perbedaan Gaya Kognitif dan Gender. Kreano, Jurnal Matematika KreatifInovatif, 9(2), 139-148.

Nurhayati, E. (2018). Psikologi Perempuan dalam Berbagai Perspektif. Pustaka Pelajar.

Raya, A. K. (2019). Pengaruh Model Pembelajaran Superitem Berbantuan Scaffolding Terhadap Kemampuan Pemecahan Masalah Matematis Peserta Didik Kelas VIII SMP Negeri 2 Pesawaran Tahun Ajaran 2016/2017. UIN Raden Intan Lampung.

Rostika, D., \& Junita, H. (2017). Peningkatan Kemampuan Pemecahan Masalah Siswa SD dalam Pembelajaran Matematika dengan Model Diskursus Multy Representation (DMR). EduHumaniora| Jurnal Pendidikan Dasar Kampus Cibiru, 9(1), 35-46.

Sundayana, R. (2016). Kaitan antara Gaya Belajar, Kemandirian Belajar, dan Kemampuan Pemecahan Masalah Siswa SMP dalam Pelajaran Matematika. Mosharafa: Jurnal Pendidikan Matematika, 5(2), 75-84.

Suratmi, S., \& Purnami, A. S. (2017). Pengaruh Strategi Metakognitif terhadap Kemampuan Pemecahan Masalah Matematika Ditinjau dari Persepsi Siswa terhadap Pelajaran Matematika. UNION: Jurnal Ilmiah Pendidikan Matematika, 5(2).

Susilowati, J. P. A. (2016). Profil Penalaran Siswa SMP dalam Pemecahan Masalah Matematika Ditinjau dari Perbedaan Gender. Jurnal Review Pembelajaran Matematika, 1(2), 132-148.

Ulya, H., \& Kartono, A. R. (2014). Analysis of Mathematics Problem Solving Ability of Junior High School Students Viewed from Students' Cognitive Style. Journal of Education and Practice, 2(10), 577-582. 